\title{
Peer victimization at school and associated factors in Campeche, Mexico
}

Héctor Javier Sánchez-Pérez 1

https://orcid.org/0000-0003-0215-1702

Edith Zúñiga Vega 2

(iD) https://orcid.org/0000-0001-7405-7024

Ángel Sinaí Sosa Salazar 3

https://orcid.org/0000-0002-6453-2060

Sergio Alvarado Orellana 4

https://orcid.org/0000-0001-6812-4446

\author{
Natalia Romero-Sandoval 5 \\ iD https://orcid.org/0000-0003-2891-3496 \\ Miguel Martín 6 \\ D https://orcid.org/0000-0003-2053-1039
}

\footnotetext{
1 Departmento de Salud. El Colegio de la Frontera Sur (ECOSUR). Carretera Panamericana y Periférico Sur S/N, Barrio María Auxiliadora, 29290, San Cristobal de Las Casas, Chiapas, Mexico. E-mail: hsanchez@ecosur.mx

2,3 Asociación TechPalewi. Pitágoras 567, Colonia Narvarte, 03020, Mexico City, Mexico.

4 Facultad de Ciencias de la Salud. Universidad de Tarapacá. Calle 18 de Septiembre Número 2222, Arica, Chile.

5 Escuela de Medicina. Universidad Internacional del Ecuador. 170113, Quito, Ecuador.

6 Unidad de Bioestadística y Epidemiología. Facultad de Medicina. Universidad Autónoma de Barcelona. 08193, Bellaterra, Barcelona, Spain.
}

\begin{abstract}
Objectives: to estimate the prevalence of peer victimization (VI-P) and to identify factors associated to it.

Methods: a cross sectional study based on a state-representativesample; 2555 students from primary and secondary schools of Campeche, in the academic year 2015-2016 participated. They were interviewed face to face. VI-P was analyzed by sex, age and various schoolrelated aspects with prevalence rate and $95 \%$ confidence interval. The analysis of interactions among the studied factors was carried out using a hierarchical log-lineal model. With the significant terms, a multiviarite analysis using a logistic model was performed. Based on this model, maximum and minimum predictive values for VI-P were calculated by odds inverse transformation.

Results: the global prevalence of VI-P was $60.4 \%(C 195 \%=58.6-62.3)$. The prevalence of violence physical, psycho-emotional, patrimonial, and sexual, were 28.8, 52.9, 26.5, and $8.7 \%$, respectively. Students in the first year, who were male, had classes scheduled in the evening, attended a public school and resided in a municipality of high/highest margination index, had the highest probability (75.3\%) of suffering VI-P.

Conclusions: given the high levels of VI-P found, and its possible effects, it is necessary implement truly effective measures to prevent it.
\end{abstract}

Key words Victimization, Bullying, Mexico

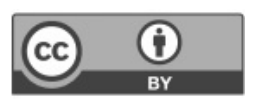




\section{Introduction}

In Mexico, the right of children to quality basic education is stipulated in Art. 3 of the Political Constitution, which specifies that the state will harmoniously develop all human faculties, respect rights and contribute to improve coexistence. ${ }^{1}$

Although peer violence in childhood is not new, and is even common in the process of their socialization, awareness of and an education to show respect towards others implies the intervention of adults to set appropriate and clear limits, ${ }^{2}$ this being the case in school settings.

School, ideally considered as one of the main places for shaping and developing children's potential to the maximum, can also be a place which involves high levels of risk for them, as has been documented by numerous studies on violence in school settings. ${ }^{3-5}$

Victimization by peers at school (VI-P) is defined as the presence of physical, psychoemotional, patrimonial or sexual violence received from school peers. 6 Meta-analyses have demonstrated the negative relationship between peer victimization (repeated harassment, power unevenness between stalker and victim, intention to cause harm by the offender) and mental and physical health.7 VI-P is a growing psychosocial and health problem affecting a considerable number of children and adolescents which, depending on the intensity of inflicted violence, can have a variety of serious consequences, negatively affecting their self-esteem, school performance and development, school dropout, depression, mental health problems, psychosomatic alterations, inability to relate with others, and -inextreme cases- suicidal ideation and suicide.6,8-11 It is also associated with the reception, and perpetration of violence towards women, as well other forms of adult violence.

Estimates in northern hemisphere western countries suggest that bullying (a form of victimization) prevalence rate is between $5 \%$ and $20 \% .12$ In Mexico, around $70 \%$ of children in primary and secondary schools suffer from VI-P. ${ }^{13}$ In a previous study of youth violence, carried out at a secondary school in Ciudad el Carmen, Campeche, 14 the maintypes of violence reported were: school violence/ bullying $(60.2 \%)$, domestic violence $(53.9 \%)$ and social violence $(43.4 \%)$.

Additionaly, in Mexico, it is considered that $60 \%$ of completed suicides among children and adolescents are associated with bullying and peer violence, making Mexico the leading country worldwide for problems of this kind. 15 At national level, in 2015 the state of Campeche ranked third in terms of suicides in general (9.1 versus 5.2 per 100,000 inhabitants), four of every 10 suicides corresponding to the population group aged $15-29$ years, and $4 \%$ to the group aged 10-14 years. In the group aged 15-29 years, in 2015 the suicide rate in the country as a whole was 8.2 per 100,000 (12 males and 3.9 females) while in Campeche it was 14.1 per 100,000, ranking again in third place. ${ }^{16}$ In this sense, the analysis of VI-P can contribute to understand one of the risk factors of this significant problem.

Given this situation, as well as an explicit interest on behalfof the Campeche educational authorities, we undertook a study aiming to estimate the prevalence of peer victimization in primary and secondary schools, and to identify if demographic characteristics (sex and age of the students), as well as details of the type of school attending (school shift, type of school, school grade, among others), and marginalization index, are associated with it.

\section{Methods}

A cross-sectional study, was conducted among a state-representative, multi-stage, stratified sample design, selected from a universe of 149931 students -of whom $61.7 \%$ were in primary school- enrolled in the 2015-2016 school year in the state of Campeche. Strata were established based on two criteria: school category (primary and secondary) and margination index (low, and very low). ${ }^{17}$ Each stratum was proportional to the size of the municipality of residence. Within each stratum, students were selected by simple random sampling. The whole sample obtained consisted of 2555 participants, considering a sampling error of $5 \%$ with a confidence level of $95 \%$.

The state of Campeche is situated on the southern border of the country. In 2015 it had a population of 899931 inhabitantes, distributed in 11 municipalities (Figure 1), two of which (Campeche, the state capital, and Ciudad del Carmen) account for $59 \%$ of the total population, and are considered to have socioeconomic margination levels of very low and low. 17 Three quarters of the Campeche population live in urban localities (towns with more than 2500 inhabitants). According to state of Campeche official figures for 2015,18 the average number of years of schooling among those aged 15 or over was 9.1 years (similar to the figure of 9.2 years for the country as a whole), while $7.6 \%$ had never gone to school. In the group aged 6-11 years, $97.7 \%$ attended school, and $93.3 \%$ did so among those aged $12-14$ years. 
Once the sample size had been determined, lists of all enrolled students were obtained, which provided the basis of a sampling frame for choosing the students to be included in the study. Students in primary and secondary courses and who were at school during the day of the survey, were invited to participate. If the selected student was not at school, a replacement was chosen, in the same year and school course, and of the same sex.

We studied 365 schools: 214 primary schools (176 of the morning shift), and 151 secondary schools (133 of the morning shift). Of the 2555 interviewed students, $50.2 \%$ were male; $60.5 \%$ were in primary, and $39.5 \%$ in secondary education; 2108 $(82.4 \%)$ had classes scheduled in the morning, and $2250(87.9 \%)$ attended a public school. Considering both primary and secondary grades, 597 (23.3\%) were in their first year of that course. The study was carried out in the 2015-2016 school year in the six selected municiaplities (Calkiní, Calakmul, Escárcega, Carmen, Palizada and Campeche city) of the state of Campeche.

Surveys were carried out face-to-face by trained interviewers, in places of the school that guaranteed the privacy (empty classrooms or offices, playgrounds, among others), and they were anonymous.
We used a questionnaire developed for the study, based on instruments used previously by our research team, dealing with social and school-related violence in several southern states of Mexico. $8,14,19$ The questionnaire was piloted with children from schools not chosen for the study. It contained various sections, including: 1. Demographic information (sex and age of the student); 2. School system workrelated data: schoolshift (morning, afternoon), course (primary, secondary), grade (first to $6^{\text {th }}$ grade in primary schools; first to third grade in secondary) and type of school (public, private); another section asked whether they had been at least once the victim of violence from peers (physical, psycho-emotional, patrimonial or sexual) at any time during the current academic year, as well as their reactions to any violence received from peers, and their response to such violence. 20

The variable outcome was VI-P defined as the presence of at least one episode of physical, psychoemotional, patrimonial or sexual violence received from school peers during the current academic year. Table 1 presents definitions of the various components of variable VI-P. The variables considered to be factors possibly associated to the presence of VI-P were: course(CE): primary/secondary; school

Figure 1

Campeche, Mexico.

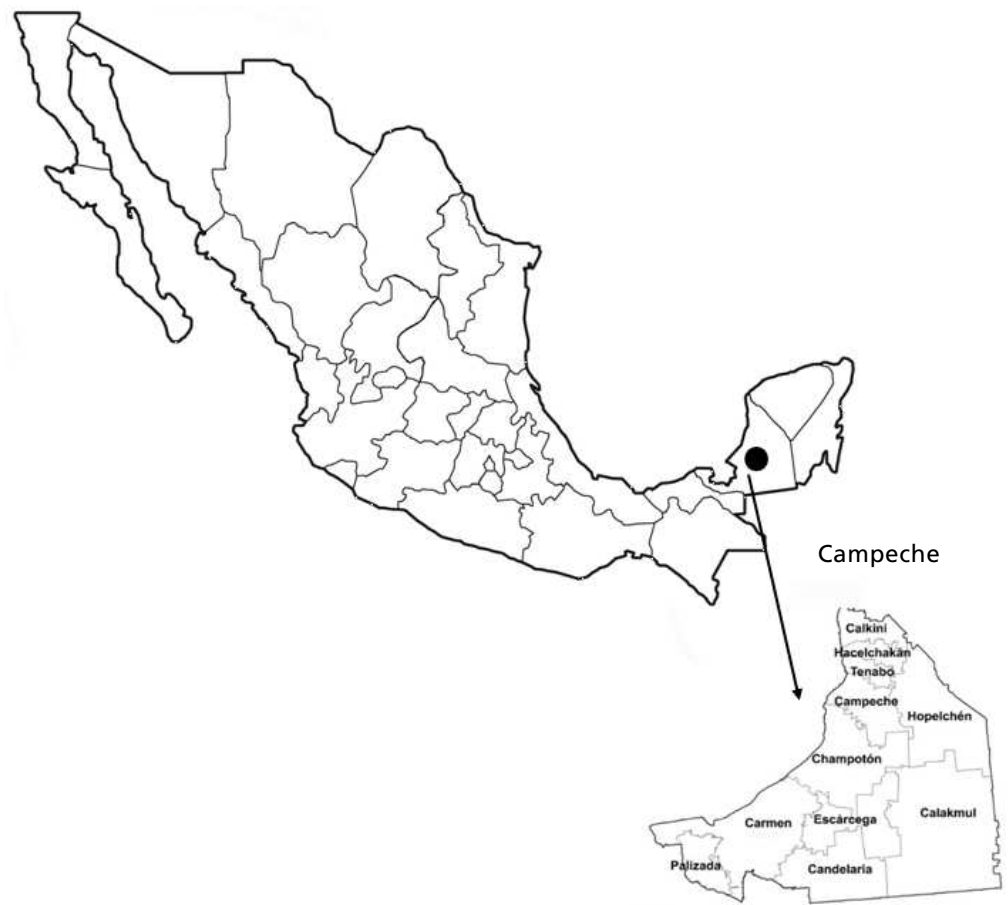


hours (SS): morning/evening; school type (S): public/private; first-year student in the school (FY): yes/no; margination index (MI): low-very low/medium-high; and sex $(\mathrm{G})$ : male/female.

Through strict selection and training of interviewers (psychologists and social workers, with extensive experience in field work), as well as the application of the anonymous surveys and in conditions of absolute privacy, potential sources of bias were controlled.

The analyzed variables are described in terms of absolute and relative frequencies. Strength of association between the variable of interest (VI-P) and the factors studied was described by prevalence ratios (PR) and their $\mathrm{CI} 95 \%$.

The analysis of interactions among the studied factors was carried out using a hierarchical log-lineal model. A $p$-value of 0.05 was considered as the cutoff point for statistical significance. With the significant terms with the outcome variable found in the log-linear model, a multiviarite analysis was carried out using a logistic model whose results were

Table 1

Operationalization of types of violence (physical, psycho-emotional, cybernetic, patrimonial and sexual) by peers.

\begin{tabular}{ll}
\hline Type of violence & \multicolumn{1}{c}{ Items* } \\
\hline Physical & In this school-year ... \\
& Have you been hit, pushed, kicked, tripped up, had stones or other objects \\
& thrown at you, been pulled by your hair, had your clothes dirtied, stained or \\
& wetted, been burned, or forced to eat disgusting things or things you didn't \\
& like? \\
& Have you been forced to do things you didn't want to, threatened with \\
& being hit or by saying things like "if you don't do such and such, you will be \\
& given a rough time, or something will happen to you"?
\end{tabular}

Psycho-emotional

Cybernetic

Patrimonial

Sexual
In this school-year...

Have you been insulted with rude remarks, been given an ugly nickname, made fun of, had jokes played on you that you didn't like, or been offended somehow?

Have you been made fun of due to your physical appearance: such as that you are skinny, or fat, or have pimples or acne, that you are tall, short, dark, pale, because of your type of hair, or because you wear glasses, etc.?

Have you been made fun of due to the way you are: such as the way you talk, your laugh, the way you walk or run, the way you play or dress, or some other thing?

Have schoolmates left you out of activities or games, or made you feel like you weren't there, that you didn't exist or were not worth anything?

Has anyone molested you through phone calls, e-mails, chats or on social networks (Facebook, Twitter, WhatsApp, etc.)?**

In this school-year...

Has anyone stolen, hidden or broken things of yours (money, equipment, school supplies, instruments, clothes, lunch, etc.?

In this school-year...

Have any of your companions molested you with things or jokes to do with your intimate parts, for example touching yours, or making you touch someone else's, bottom, penis, vulva; have they shown you or made you show them your intimate parts, tried to undress you, kiss you by force, or do anything else that you didn't want to do?

\footnotetext{
* For all types of violence, the answer categories were: Yes / No. If yes, What happened?, How many times? (Once / a few times / often / always). For the global response about violence by peers we only took into account the categories yes / no.

** This item only was asked to secondary school students. Consequently, it was not included in the answer variable (VI-P).
} 
expressed as adjusted OR values and their 95\% confidence intervals. Finally, based on this model we calculated maximum and minimum predictive values for VI-P expressed as probabilities, calculated by odds inverse transformation.21 Data was analyzed using the Statistical Package for Social Sciences, version 21.22

Interviewers were trained in emotion-containment techniques, just in case a participant needed psychological care (though there were no cases that required psycho-emotional support). All necessary permissions were obtained from the Campeche Ministry of Public Education and from authorities of each school included in the study. Ethical approval for the study was obtained from the Research Ethics Committee of El Colegio de la Frontera Sur.

At the time the selected students were invited to participate in the study, they were read the informed consent sheet. If the students agreed to participate, they recived the indication to take it to their homes to obtain the approval of their parents. Those who did not provide written informed consent, both from their parents and from themselves, were excluded. The non-response rate obtained was under $2 \%$.

\section{Results}

The global prevalence of VI-P was $60.4 \%$ (CI95\% $=$ 58.6-62.3). Table 2 presents the distribution of VI-P by violence by studied factors. The prevalence of violence physical was $28.8 \%(\mathrm{CI} 95 \%=26.3-29.7)$, psycho-emotional $52.9 \%(\mathrm{CI} 95 \%=51.0-54.8)$, patrimonial $26.5 \%(\mathrm{CI} 95 \%=24.8-28.2)$, sexual $8.7 \%$ $(\mathrm{CI} 95 \%=8.6-8.9)$, and, among the secondary students, the violence through cybernetic means, was $11.2 \%(\mathrm{CI} 95 \%=9.5-12.3), 7.1 \%$ among boys, and $15.4 \%$ for girls, $p<0.05$.

Table 3 shows the interactions terms by hierarchical log linear model which were statistically significant.

Table 4 presents associations between VI-P and the factors included in the study. After performing multivariate adjustments, we observed significant adjusted OR (ORadj) values for all analyzed factors, except course $($ ORadj $=0.88 ; \mathrm{CI} 95 \%=0.74-1.05)$ and school hours $($ ORadj $=1.22 ;$ CI95\% $=0.78-1.91)$. The significant interaction terms with the response variable, continued to be after adjusting for the other factors, showing a strong interaction with being in the first year of school, wheter primary or secondary.

On the basis of this model, we found that students in the first year - primary or secondary-,

Table 2

\begin{tabular}{|c|c|c|c|c|c|}
\hline \multirow[t]{2}{*}{ Variable } & \multirow[t]{2}{*}{$\mathbf{N}$} & \multicolumn{2}{|c|}{ VI-P } & \multirow[t]{2}{*}{ PR } & \multirow[t]{2}{*}{$\mathrm{Cl} 95 \%$} \\
\hline & & $\mathrm{n}$ & $\%$ & & \\
\hline Gender & & & & 0.96 & $0.90-1.02$ \\
\hline Female & 1271 & 751 & 59.1 & & \\
\hline Male & 1284 & 794 & 61.8 & & \\
\hline Margination index & & & & 1.15 & $1.06-1.24$ \\
\hline High/highest & 1888 & 1182 & 62.6 & & \\
\hline Low/lowest & 667 & 363 & 54.4 & & \\
\hline Level of study & & & & 0.95 & $0.90-1.02$ \\
\hline Primary & 1544 & 916 & 59.3 & & \\
\hline Secondary & 1011 & 629 & 62.2 & & \\
\hline School hours & & & & 1.14 & $1.05-1.22$ \\
\hline Evening & 448 & 300 & 65.0 & & \\
\hline Morning & 2107 & 1245 & 59.1 & & \\
\hline School type & & & & 1.08 & $0.98-1.20$ \\
\hline Public & 2246 & 1371 & 61.0 & & \\
\hline Private & 309 & 174 & 56.3 & & \\
\hline First year & & & & 1.04 & $0.97-1.12$ \\
\hline Yes & 595 & 372 & 62.5 & & \\
\hline No & 1960 & 1173 & 59.8 & & \\
\hline
\end{tabular}

$\mathrm{VI}-\mathrm{P}=$ Victimization by peers at school; $\mathrm{PR}=$ Prevalence rate; $\mathrm{Cl}=$ confidence interval. 
Table 3

Descriptive of interactions terms, second and third order, by hierarchical log linear model.

\begin{tabular}{lcc}
\hline Interaction terms & Partial Chi-square test & Sig. \\
\hline School category * Peer Victimization & 5.03 & 0.03 \\
School hours * Peer Victimization & 5.82 & 0.02 \\
Margination Index * Peer Victimization & 13.87 & 0.00 \\
School hours * Gender * Peer Victimization & 4.37 & 0.03 \\
School category * First year student * Peer Victimization & 11.87 & 0.00 \\
School hours * First year student * Peer Victimization & 7.23 & 0.00 \\
Gender * First year student * Peer Victimization & 7.38 & 0.00
\end{tabular}

Total G2= 4614.508; freedom degrees: $20 ; \mathrm{G}^{2}$ explained from original: $91.8 \%$.

Table 4

\begin{tabular}{lcccc}
\hline \multicolumn{2}{l}{ Associations for violence by peer using logistic model with interactions. } & & \\
\hline Variable & Crude OR & Cl95\% & Adjusted OR & Cl95\% \\
\hline Gender & 1.12 & $0.96-1.32$ & 1.62 & $1.16-2.28$ \\
Margination index & 1.41 & $1.17-1.68$ & 1.42 & $1.18-1.70$ \\
Level of study & 0.89 & $0.75-1.04$ & 0.88 & $0.74-1.05$ \\
School hours & 1.40 & $1.13-1.74$ & 1.22 & $0.78-1.91$ \\
School type & 1.21 & $0.96-1.54$ & 2.64 & $1.63-4.28$ \\
First year & 1.12 & $0.93-1.35$ & 4.22 & $2.03-8.77$ \\
School type * First year & - & - & 0.40 & $0.23-0.70$ \\
School hours * First year & - & - & 0.54 & $0.33-0.90$ \\
Gender * First year & - & - & 0.63 & $0.43-0.92$
\end{tabular}

Baseline category: not First-year, private school, morning school hour, female gender, secondary level of study, high/very high margination index. Reference odds: 0.40

who were male, had classes scheduled in the evening, attended a public school and resided in a municipality of high/highest margination index, had the highest probability $(75.3 \%)$ of suffering VI-P, whereas those who were the least likely $(36.9 \%)$, were their counterparts with opposing values of these variables.

\section{Discussion}

It is alarming to find that $60.4 \%$ of the students interviewed had suffered at least one episode of some form of VI-P at school in the academic year studied. The VI-P prevalence at school found in the present study coincides with that reported by our research working-group in a case study of one secondary school in Ciudad el Carmen, Campeche, namely a prevalence for this type of violence of $60.2 \% .{ }^{14}$

As noted in the introduction, VI-P can have a variety of serious physical and psycho-emotional consequences, among which stands out, in extreme cases, suicidal ideation. In 2015, in the state of Campeche, four of every 10 suicides corresponded to the population group aged $15-29$ years, and $4 \%$ in the group aged 10-14 years. 16 Of course, studies are needed to analyze ingreater depth how much VI-P can contribute to suicidal ideation among the school population.

The Mexican ECOPRED 2014 survey (Social Cohesion Survey for Prevention of Violence and Delinquency) ${ }^{23}$ found that the state of Campeche presented a bullying prevalence of $34.0 \%$ among students aged 12 to 18 years, who had been victims of some type of criminal behaviour or mistreatment at school during 2014, a figure which was above the percentage for the country as a whole, of $32.2 \%$. Moreover, that survey found that $70.7 \%$ of students aged 12 to 29 years had been victims of criminal acts or mistreatment at school during 2014, while in the country as a whole, the corresponding figure was $66.5 \%$.

Several studies have shown a prevalence rate of 
peer-violence between $49.7 \%$ to $94.0 \%$ in boys and $43.3 \%$ to $85.0 \%$ in girls. $3,9,24$ In Uganda, among primary school students, Ojiambo et al. 5 found a prevalence of $47 \%$ of children that reported having suffered, at some point, some form of peer victimization, with $21 \%$ having experienced it in the previous week. Kumar et al. 4 in a study of schoolattending adolescents in Kerala, India, found prevalence rates (last-year and lifetime, respectively) of physical abuse $75.5 \%$ and $78.5 \%$, emotional abuse 84.5 and $85.7 \%$, and sexual abuse 21.0 and $23.8 \%$.

It should be note that, in our study, the prevalence of sexual violence found $(8.7 \%)$, only refers to the "private parts" (Table 1), and we didn't delve into other aspects, as consummating sexual violence and gender stereotypes, among others. Consequently, such prevalence may be higher.

In regard to gender-related peer violence, Serrano 10 points out that in general, perpetrators of bullying at school are more often males than females, as well as boys are more violent than girls. Males tend to use physical violence more frequently, while females use verbal and emotional violence. Among the factors that stimulate differences between boys and girls, it stands out that males are receptors of more social incentives to show violent behaviours, while girls are instructed to develop more passive and docile roles 8 ; moreover, males are also victims of other male agressors in school settings. 3,4 A study carried out by the Mexican National Institute for Evaluation of Education (INEE) 25 among primary and secondary school students, found higher prevalences of victims of violence among boys $(21.6 \%$ and $20.0 \%$, respectively) than among girls ( $18.3 \%$ and $16.5 \%)$.

One notable aspect found in this study, is that to be in the first year in a school (primary or secondary) is another risk factor for exposure to higher levels of peer violence. In this regard, it is worth mentioning the phenomenon, common in Mexico, of "novatadas" (hazing) perpetrated on students of recent incorporation into educational institutions, by older students, which in recent times has acquired progressively more violent and dramatic forms. Researchers claim that hazing can contribute to an offensive school environment and restrict a positive learning setting for students. 26,27

On the other hand, although in the bivariate analysis the type of school (public-private) remained on the border of statistical significance (Table 2), when adjusting for the rest of the analysed variables, it can be seen that there is a greater possibility of suffering VI-P when being in a public school (Table 4).
With respect to our finding about more VI-P in municipalities of high/highest index margination, in comparison to the rest, some studies showed that low economic status of the family increases the risk of experiencing violence. ${ }^{28}$ According to Vernieri, 29 violence in classrooms is intimately related to social crisis, because schools located in marginal sectors, where families use any means and practices available in order to survive, work with students in "permanent risk of violence".

The log-linear analysis showed that VI-P in schools is a complex issue, and revealed the importance of certain factors which, taken separately, did not present clear differences in accounting for the prevalence of the forms of violence analyzed. These factors, analyzed by logistic model, showed the importance of introducing interaction terms, since without them the effects would have been overestimated, as is the case of being in the first year of a course.

For example, if joint-calculated, the OR for school type (public/private) and first year students -always under the assumption of these two variables being independent- the result would be an ORadj of $11.14(2.64 * 4.22)$, whereas ORadj considering the correction for the interaction of these two variables was $4.45(2.64 * 4.22 * 0.40)$. As Table 4 shows, the three interaction factors reduce the simultaneous effect of the components of the interaction, assuming them to be independent, and are significant.

This study has several limitations. One aspect linked with violence at school is domestic violence due to its influence on learning and reproduction of violence. 3,8 This factor was not possible to register due to specific recommendations of the Research Ethical Committee of El Colegio de la Frontera Sur, in order to avoid this aspect in studies involving populations of school children. This was done to protect children from possible repercussions by parents, fearful that a child might give information about violence at home (were this to be the case).

Secondly, we chose not to analyze peer violence at school in terms of academic performance, in order to avoid generating mistrust among children. It must be remembered that the interviews were anonymous, precisely to generate a climate of trust between researchers and students.

In third place, we did not study such factors as the psychological, interpersonal, and physiological transitions that are present in early adolescence. 30 Finally, with regard of sexual violence, we only limited to "private parts" and we didn't go deeper into others of its elements.

High levels of peer violence in schools was 
found in this study. Since high levels of VI-P can turn out into severe physical and psycho-emotional damage, which can lead to suicide, it is necessary to have other studies that address aspects not included in this one, so that school authorities may implement truly effective measures to prevent violence by peers, for example, include courses/workshops on human rights, assertiveness, self-esteem, gender and non-violent conflict resolution.

\section{Authors' contribution}

Sánchez PHJ, Zúñiga VE conceived the study, participated in study design and coordinated the project. Sánchez PHJ, Sosa SSA performed and coordinated field work. Alvarado OS outlined the design and simple size of the study. Sánchez-PHJ,

\section{References}

1. Cámara de Diputados del H. Congreso de la Unión. Constitución Política de los Estados Unidos Mexicanos. Texto vigente, Última reforma publicada DOF 27-08-2018. 2018. [fecha de acceso: 27 de septiembre 2019]. Disponible en: http://www.diputados.gob.mx/LeyesBiblio/pdf/1_ 270818.pdf

2. UNICEF. Plan Internacional \& Fondo de las Naciones Unidas para la Infancia (UNICEF).Violencia escolar en América Latina y el Caribe: Superficie y fondo [School violence in Latin American and the Caribbean: surface and bottom]. 2011 [fecha de acceso: 16 de mayo 2019]. Panamá, República de Panamá. Available in: https://www.unicef.org/costarica/docs/cr_pub_Violencia_es colar_America_Latina_y_Caribe.pdf

3. Corboz J, Hemat O, Siddiq W, Jewkes R. Children's peer violence perpetration and victimization: prevalence and associated factors among school children in Afghanistan. PloS One. 2018;13(2): e0192768.

4. Kumar MT, Kumar S, Singh SP, Kar N. Prevalence of child abuse in school environment in Kerala, India: An ICASTCI based survey. Child Abuse Negl. 2017; 70: 356-63.

5. Ojiambo WS, Clarke K, Knight L, Allen E, Walakira E, Namy S, Naker D, Devries K. Violence against children perpetrated by peers: A cross-sectional school-based survey in Uganda. Child Abuse Negl. 2017;68: 65-73.

6. Van Geel M, Vedder P, Tanilon J. Relationship Between Peer Victimization, Cyberbullying, and Suicide in Children and Adolescents. JAMA Pediatr. 2014;168(5): 435-42.

7. Gini G,Pozzoli T. Association between bullying and psychosomatic problems: A meta-analysis. Pediatrics. 2009;123(3): 1059-65.

8. Zúñiga-Vega E, Sánchez-Pérez HJ, Orihuela-Ordóñez D. De Frente a la Violencia Familiar. Lineamientos y
Sosa SSA, Vega ZE provided training field staff. Romero SN, Mateo MM, Alvarado OS performed statistical analysis. Sánchez PHJ, Romero SN, Mateo MM drafted the manuscript. Zúñiga VE, Alvarado OS, Sosa SSA contributed to the correction and critical review of the article. All authors read and approved the final version of the manuscript and are publicly responsible for the content of the article.
Recomendaciones para su Comprensión, Prevención y Apoyo a Personas que viven esta condición. 1 ed. Mexico City: El Colegio de la Frontera Sur, Asociación TechPalewi A.C.; 2010.

9. McFarlane J, Karmaliani R, Maqbool Ahmed Khuwaja H, Gulzar S, Somani R, SaeedAli T, Somani YH, ShehzadBhamani S, Krone RD, Paulson RM, Muhammad A, JewkesR. Preventing peer violence against children: methods and baseline data of a cluster randomized controlled trial in Pakistan. Glob Health: Sci Pract. 2017; 5 (1): 115-37.

10. Serrano A. Acoso y Violencia en la Escuela. Cómo detectar, Prevenir y Resolver el Bullying. 1 ed. Madrid: Ariel Ed; 2006.

11. Cobo-Ocejo P, Tello-Garrido R Bullying en México. Conducta violenta en niños y adolescentes. México, D.F.: Quarzo; 2008.

12. Nansel TR, Craig W, Overpeck MD, Saluja G, Ruan W J. Cross-national consistency in the relationship between bullying behaviors and psychosocial adjustment. Arch Pediatr Adolesc Med. 2004; 158 (8): 730-6.

13. Bullying Without Borders. Estadísticas mundiales de Bullying 2017/2018. Primer Trabajo Oficial en el Mundo contra el Bullying. [fecha de acceso: 2 Junio 2020]. Disponible en: https://bullyingsinfronteras.blogspot.com/ 2018/10/estadisticas-mundiales-de-bullying_29.html

14. Sánchez-Pérez H, Zúñiga-Vega E, Sosa-Salazar Á. Estudio de caso sobre el fenómeno de "Jóvenes y Violencia" en la Escuela Secundaria Técnica No. 21 de Ciudad el Carmen, Campeche, 2013. San Francisco de Campeche, Campeche, México: El Colegio de la Frontera Sur, Asociación TechPalewi; 2013. 
15. Maldonado S. En México, $60 \%$ de los suicidios en menores son por bullying: especialista. La Jornada Baja California 16 de mayo de 2016 [fecha de acceso: 21Agosto 2020]. Disponible en: https://jornadabc.mx/tijuana/16-05-2016/enmexico-60-de-los-suicidios-en-menores-son-por-bullyingespecialista

16. INEGI (Instituto Nacional de Estadística y Geografia) Estadísticas a propósito del día mundial para la prevención del suicidio.Datos Nacionales. 2017. [fecha de acceso: 19 Diciembre 2018]. Disponible en: https://es.slideshare.net/ omarhola/estadsticas-a-propsito-del-da-mundial-para-laprevencin-del-suicidio

17. CONAPO (Consejo Nacional de Población). Índice de marginación por entidad federativa y municipio 2010 Anexo B2. 1 ed. México, Distrito Federal; 2011.

18. INEGI (Instituto Nacional de Estadística y Geografía). Cuéntame. Información por entidad. Campeche. 2015 [fecha de acceso: 19 Diciembre 2018]. Disponible en:http://cuentame.inegi.org.mx/monografias/informacion/camp/poblacion/educacion. asp $x$ tema $=$ me \&e $=04$

19. Méndez-Sántiz H, Sánchez-Pérez H. Violencia en el noviazgo en población escolar de preparatorias en San Cristóbal de Las Casas, Chiapas. In: Cruz-Burguete J, NazarBeutelspacher A, editors. Sociedad y desigualdad en Chiapas: Una mirada reciente. San Cristóbal de Las Casas, Chiapas: El Colegio de la Frontera Sur; 2009. p. 49-91.

20. Sánchez-Pérez H， Zúñiga-Vega E， Sosa-Salazar Á.Violencia y acoso escolar en las escuelas de educación básica del Estado de Campeche. Informe final de resultados. San Francisco de Campeche, Campeche, México. Asociación TechPalewi, Secretaría de Educación del Estado de Campeche, El Colegio de la Frontera Sur; 2017.

21. Agresti A. Categorical Data Analysis. 3 ed. New Jersey: John Wiley and Sons Inc.; 1990.

22. SPSS for Windows version 15.0. 1 ed. Chicago: SPSS Inc; 2012

Received on December 23, 2019

Final version presented on August 25, 2020

Approved on September 1, 2020
23. INEGI (Instituto Nacional de Estadística y Geografía). Encuesta de Cohesión Social para la Prevención de la Violencia y la Delincuencia. ECOPRED, 2014. 1 ed. Aguascalientes, Aguascalientes: INEGI; 2015.

24. Siziya S, Rudatsikira E, Muula AS. Victimization from bullying among school-attending adolescents in grades 7 to 10 in Zambia. J Inj Violence Res. 2012; 4 (1): 30-35.

25. INEE (Instituto Nacional para la Evaluación de la Educación). Disciplina, violencia y consumo de sustancias nocivas a la salud en escuelas primarias y secundarias de México. 1 ed. Mexico City; 2007.

26. Graupensperger S, Benson A J, Bray BC, Evans MB. Social cohesion and peer acceptance predict student-athletes' attitudes toward health-risk behaviors: a within-and betweengroup investigation. J Sci Med Sport. 2019; 22 (12): 1280-

27. Hakkola L, Allan EJ, Kerschner D. Applying utilizationfocused evaluation to high school hazing prevention: a pilot intervention. Eval Progr Plan. 2019; 75: 61-8.

28. Stalmach M, Tabak I, Radiukiewicz K. Selected family socio-economic factors as predictors of peer violence among school children in Poland. Dev Period Med. 2014; 18 (4): 495-505.

29. Vernieri MJ. Violencia escolar. ¿Se puede hacer algo? Propuestas y taller de reflexión. Buenos Aires, Argentina: Bonum; 2010

30. Troop-Gordon W. Peer victimization in adolescence: The nature, progression, and consequences of being bullied within a developmental context. J Adolesc. 2017; 55: 11628 